\title{
Pembentukan Identitas Remaja di Yogyakarta
}

\author{
Darmawan Muttaqin ${ }^{1}$ Endang Ekowarni ${ }^{2}$ \\ Fakultas Psikologi Universitas Gadjah Mada
}

\begin{abstract}
Context has been identified as an important factor of identity formation among adolescents. The aim of this study was to understand adolescent identity formation component in Indonesian context especially in Yogyakarta, considering gender differences, age groups, and correlation between components as well. This study involved 450 Indonesian adolescents aged 12-21 years (225 boys and 225 girls) that constituted of early, middle, and late adolescents. This study used Identity Style Inventory to assess identity style (informational, normative, and diffuse-avoidant), Utrecht-Management of Identity Commitments Scale to assess the identity dimensions (commitment, in-depth exploration, and reconsideration of commitment), and Ego Identity Process Questionnaire to assess identity status (diffusion, foreclosure, moratorium, and achievement). Results showed there were significant differences in identity styles, dimensions, and statuses by considering gender and age groups. The correlation between adolescent's identity styles, dimensions, and statuses was also found in the Indonesian context.
\end{abstract}

Keywords: identity dimensions, identity formation, identity status, identity style

\begin{abstract}
Abstrak. Konteks telah diidentifikasi sebagai faktor yang penting dari pembentukan identitas remaja. Penelitian ini bertujuan untuk memahami komponen pembentukan identitas remaja pada konteks Indonesia khususnya di Yogyakarta, terutama terkait perbedaan gender dan kelompok usia serta keterkaitan antar komponen pembentukan identitas. Partisipan penelitian adalah 450 (225 laki-laki dan 225 perempuan) remaja Indonesia berusia 12-21 tahun yang terdiri dari remaja awal, tengah, dan akhir. Alat ukur Identity Style Inventory, Utrecht-Management of Identity Commitments Scale, dan Ego Identity Process Questionnaire digunakan untuk mengukur gaya identitas (informatif, normatif, dan menunda-menghindar), dimensi identitas (komitmen, eksplorasi mendalam, dan peninjauan kembali komitmen), dan status identitas (diffusion, foreclosure, moratorium, dan achievement). Hasil penelitian menunjukkan ada perbedaan gaya, dimensi, dan status identitas ditinjau dari gender dan kelompok usia. Keterkaitan antara gaya, dimensi, dan status identitas remaja juga ditemukan pada konteks Indonesia.
\end{abstract}

Kata kunci: dimensi identitas, gaya identitas, pembentukan identitas, status identitas

Pembentukan identitas merupakan tugas perkembangan yang utama bagi remaja (Erikson, 1968). Erikson (1950)

\footnotetext{
${ }^{1}$ Korespondensi mengenai isi artikel ini dapat dilakukan melalui: darmawan.muttaqin@ staff.ubaya.ac.id dan ekowarni@ugm.ac.id
}

dalam mengembangkan teori pembentukan identitas mempertimbangkan pentingnya konteks. Para peneliti mengemukakan bahwa pembentukan identitas merupakan proses interaksi antara individu dan konteks (Adams \& Marshall, 1996; Bosma \& Kunnen, 2001; Kroger, 
2000). Bahkan, konteks telah dianggap sebagai faktor penting dari pembentukan identitas (Côté \& Levine, 1988; Phinney, 2005). Secara khusus Baumeister dan Muraven (1996) menjelaskan bahwa tujuan utama pembentukan identitas adalah adaptasi terhadap konteks sehingga individu terlibat dalam proses pembentukan identitas berdasarkan apa yang mereka pikirkan terhadap konteks yang mereka hadapi.

Untuk memahami pembentukan identitas yang sesuai dengan konteks tertentu, beberapa peneliti telah menunjukkan sejumlah cara yang berbeda (lihat Schwartz, Zamboanga, Meca, \& Ritchie, 2012). Pada umumnya penelitian tentang pembentukan identitas yang mempertimbangkan konteks dilakukan secara lintas negara (misalnya Bang \& Montgomery, 2013; Busch \& Hofer, 2011; Eryigit \& Kerpelman, 2011) maupun hanya di suatu negara tertentu (misalnya Laghi, Baiocco, Liga, Guarino, \& Baumgartner, 2013; Lee \& Beckert, 2012; Wängqvist \& Frisén, 2013). Pada penelitian ini, kami mencoba untuk memahami pembentukan identitas remaja pada konteks Indonesia khususnya di Yogyakarta.

Memahami pembentukan identitas remaja di Indonesia bukanlah sesuatu yang mudah karena tidak terdapat profil remaja yang seragam dan berlaku secara nasional (Sarwono, 2013). Hal ini mengingat remaja di Indonesia terdiri dari berbagai suku, adat, status sosial-ekonomi, dan tingkat pendidikan. Oleh karena itu, pemahaman mengenai konteks yaitu situasi terjadinya perkembangan individu (Santrock, 2011), dapat digunakan untuk mendeskripsikan remaja di Indonesia. Dengan demikian, remaja pada konteks Indonesia dapat didefinisikan sebagai remaja yang tumbuh dan berkembang di konteks Indonesia. Konteks Indonesia dapat dipahami sebagai situasi di Indonesia yang menjadi tempat terjadinya perkembangan individu.

Pada konteks Indonesia, mayoritas remaja tinggal dalam keluarga besar yang terdiri dari keluarga inti (suami, istri, anak) dan ditambah dengan anggota keluarga lain seperti nenek, kakek, paman, bibi, serta sanak keluarga lainnya (Shwalb dkk., 2010; Suardiman, 2011). Pada keluarga inti, sikap orang tua terhadap anak cenderung dominan dan hak orang tua atas diri anak bersifat mutlak (Sarwono, 2013). Pada umumnya, orang tua di Indonesia merasa tanggung jawab untuk mendidik anaknya sudah berakhir ketika anak mampu mengembangkan diri menjadi pribadi yang mandiri dan tidak tergantung pada orang lain (Suardiman, 2011). Mandiri dapat ditandai dengan kemampuan anak untuk tidak tergantung secara finansial, yang berarti anak sudah bekerja untuk memenuhi kebutuhannya, dan anak sudah menikah.

Berkaitan dengan pembentukan identitas yang sesuai dengan konteks, Yoder (2000) menjelaskan bahwa pembentukan identitas tergantung pada kesempatan, harapan, dan kebebasan yang dimiliki individu. Individu harus sadar bahwa mereka memiliki kesempatan untuk mengeksplorasi dan mengevaluasi alternatif identitas (Erikson, 1968). Meskipun demikian, kenyataannya tidak semua individu memiliki kesempatan yang sama. Perbedaan kesempatan tersebut dapat disebabkan oleh perbedaan gender dan kelompok usia pada konteks tertentu.

Adanya perbedaan gender dalam pembentukan identitas telah ditunjukkan oleh beberapa penelitian sebelumnya (Berman, Weems, Rodriguez, \& Zamora, 2006; Graf, Mullis, \& Mullis, 2008; Vleioras \& Bosma, 2005). Hal ini dikarenakan adanya perbedaan harapan dan proses 
sosialisasi untuk setiap gender pada setiap masyarakat (Lee \& Beckert, 2012). Adanya peran gender laki-laki dan perempuan menunjukkan perbedaan norma sosial dan harapan budaya terhadap laki-laki dan perempuan (Möller-Leimkühler, 2003). Mayoritas remaja Indonesia tumbuh dan berkembang dalam keluarga patrilineal (Utomo, 2006). Jenis kelamin biasanya memengaruhi peran dan tanggung jawab anak di dalam keluarga (Hidajadi, 2001; Shwalb dkk., 2010). Anak laki-laki memiliki tanggung jawab besar melanjutkan garis keluarga sehingga seolah lebih diperhatikan orang tua daripada anak perempuan. Anggapan bahwa anak lakilaki adalah penerus garis keluarga telah membuat posisi anak perempuan menjadi tidak menguntungkan (Hidajadi, 2001).

Selain perbedaan gender, perbedaan kelompok usia juga dapat menyebabkan perbedaan pembentukan identitas (Berzonsky, 2011; Klimstra, Hale, Raaijmakers, Branje, \& Meeus, 2010; Kroger, Martinussen, \& Marcia, 2010). Kroger dan Marcia (2011) menjelaskan bahwa pembentukan identitas yang optimal berkaitan dengan kesempatan yang dimiliki individu untuk berperan sebagai individu yang dewasa. Remaja Indonesia akan mendapatkan kesempatan untuk berperan sebagai individu yang dewasa saat memasuki masa remaja akhir yaitu sekitar usia 18-21 tahun. Pada masa remaja akhir, remaja Indonesia pada umumnya sudah lulus sekolah menengah dan masuk perguruan tinggi. Ketika remaja Indonesia masuk perguruan tinggi, tidak sedikit dari mereka yang harus berpisah dengan orang tua agar dapat melanjutkan pendidikan di perguruan tinggi yang sesuai dengan minat dan kemampuan. Pada masa remaja akhir pula, masalah mencari pekerjaan menjadi masalah yang konkret bagi remaja Indonesia (Sarwono, 2013).

Pembentukan Identitas: Gaya, Dimensi, dan Status Identitas

Pembentukan identitas digambarkan sebagai interaksi dari dua dinamika yaitu pencapaian identitas dan kebingungan identitas (Erikson, 1950, 1968). Pencapaian identitas menggambarkan individu yang mampu melakukan pengaturan diri terhadap identifikasi diri yang ideal, sedangkan kebingungan identitas merupakan ketidakmampuan untuk mengembangkan identifikasi diri yang dapat diterapkan sebagai bentuk identitas orang dewasa (Schwartz, 2001). Sebagai upaya mengoperasionalkan pencapaian dan kebingungan identitas, beberapa peneliti mengembangkan model pembentukan identitas, misalnya gaya identitas (Berzonsky, 1989), tiga faktor dimensi identitas (Crocetti, Rubini, \& Meeus, 2008), dan status identitas (Marcia, 1966).

Model gaya identitas menggambarkan pendekatan individu dalam mengeksplorasi alternatif dan membuat keputusan tentang identitas (Berzonsky, 1989). Model gaya identitas terdiri dari tiga pendekatan pemrosesan identitas yaitu gaya informatif, normatif, dan menunda-menghindar (Berzonsky, 2004, 2011). Individu dengan gaya informatif secara sengaja mencari, mengolah, dan mengevaluasi informasi yang relevan dengan identitas. Individu dengan gaya normatif akan melakukan internalisasi dan mematuhi tujuan, nilainilai, dan petunjuk dari orang lain yang signifikan dengan cara yang relatif otomatis sehingga akan membuat komitmen yang terlalu dini tanpa melakukan evaluasi dan pertimbangan. Individu dengan gaya menunda-menghindar menunjukkan keengganan untuk 
menghadapi dan mengatasi permasalahan identitas.

Model tiga dimensi identitas menjelaskan tiga dimensi pembentukan identitas yaitu komitmen, eksplorasi mendalam, dan peninjauan kembali komitmen (Crocetti dkk., 2008; Meeus, Van De Schoot, Keijsers, Schwartz, \& Branje, 2010). Komitmen mengarah pada proses memantapkan pilihan terkait dengan berbagai domain identitas yang disertai dengan rasa percaya diri terhadap pilihannya. Eksplorasi mendalam mengarah pada proses merefleksikan komitmen yang sudah dibuat, mencari informasi tambahan, dan berdiskusi dengan orang lain terkait alternatif identitas yang sudah dipilih. Peninjauan kembali komitmen mengarah pada kemungkinan untuk mengubah atau merevisi komitmen yang tidak lagi memuaskan bagi individu.

Model status identitas didasarkan pada dua dimensi pembentukan identitas yaitu eksplorasi dan komitmen yang digunakan untuk mengklasifikasikan status identitas yang terdiri dari diffusion, foreclosure, moratorium, dan achievement (Kroger \& Marcia, 2011; Marcia, 1993). Individu yang sudah mencapai komitmen melalui proses eksplorasi berada pada status achievement. Individu yang masih berusaha untuk mencapai komitmen dan masih dalam proses eksplorasi berada pada status moratorium. Individu yang sudah mencapai komitmen dengan mengambil komitmen orang lain yang signifikan dalam hidupnya berada pada status foreclosure. Individu yang belum mencapai komitmen dan menjalani proses eksplorasi berada pada status diffusion.

Gaya, dimensi, dan status identitas memiliki fokus yang berbeda dalam pembentukan identitas, tetapi beberapa peneliti telah menunjukkan kaitan ketiga hal tersebut dan menjadikannya satu kesatuan dalam konsep pembentukan identitas (Berzonsky dkk., 2013; Crocetti, Rubini, Berzonsky, \& Meeus, 2009; Zimmermann, Mahaim, Mantzouranis, Genoud, \& Crocetti, 2012). Gaya, dimensi, dan status identitas dianggap sebagai proses, struktur, dan hasil yang merupakan komponen pembentukan identitas (Schwartz \& Montgomery, 2002).

Penelitian ini mencoba untuk menguji beberapa hipotesis yaitu: (1) ada perbedaan gaya, dimensi, dan status identitas antara remaja laki-laki dan perempuan; (2) ada perbedaan gaya, dimensi, dan status identitas antara remaja awal, tengah, dan akhir; (3) ada hubungan antara gaya identitas (informatif, normatif, dan menunda-menghindar) dan dimensi identitas (komitmen, eksplorasi mendalam, dan peninjauan kembali komitmen); dan (4) ada hubungan antara gaya identitas (informatif, normatif, dan menundamenghindar) dan status identitas (diffusion, foreclosure, moratorium, dan achievement).

\section{Metode}

\section{Partisipan}

Partisipan penelitian adalah 450 remaja yang berada di Yogyakarta (225 laki-laki dan 225 perempuan) yang berusia 12-21 tahun ( $\mathrm{M}=16,34$ tahun, $\mathrm{SD}=2,62)$. Partisipan penelitian terdiri dari 150 remaja awal (75 laki-laki, 75 perempuan) yang berusia $12-15$ tahun $(M=13,34$ tahun, $\mathrm{SD}=0,59), 150$ remaja tengah (75 laki-laki, 75 perempuan) yang berusia 15-18 tahun $(\mathrm{M}=16,14$ tahun, $\mathrm{SD}=0,62)$, dan 150 remaja akhir (75 laki-laki, 75 perempuan) yang berusia 18-21 tahun ( $\mathrm{M}=19,53$ tahun, $\mathrm{SD}=0,77)$.

\section{Instrumen Penelitian}

Alat ukur yang digunakan belum pernah diadaptasi di Indonesia sehingga 
alat ukur harus diterjemahkan ke dalam bahasa Indonesia dengan menggunakan panduan dari International Test Commission (Hambleton, 2005). Ada empat tahap yang dilakukan dalam proses adaptasi alat ukur. Pertama, alat ukur diterjemahkan dari Bahasa Inggris ke Bahasa Indonesia oleh dua orang penerjemah independen. Kedua, alat ukur versi Bahasa Indonesia direviu oleh dua orang reviewer untuk memeriksa kejelasan kalimat, tingkat kesulitan kata, dan akurasi terjemahan dari Bahasa Inggris ke Bahasa Indonesia. Ketiga, alat ukur versi Bahasa Indonesia diterjemahkan kembali ke Bahasa Inggris oleh dua penerjemah independen yang berbeda dari penerjemahan awal. Terakhir, alat ukur versi Bahasa Indonesia yang sudah disempurnakan disajikan kepada beberapa partisipan untuk mengetahui pemahaman partisipan terhadap setiap aitem.

Informasi mengenai properti psikometris alat ukur diperoleh dari evaluasi model pengukuran melalui program IBM SPSS Amos 21 (Arbuckle, 2012). Model pengukuran disusun dengan melakukan pemaketan aitem yaitu menggabungkan beberapa aitem secara acak dengan menggunakan rata-rata untuk menjadi satu paket. Prosedur pemaketan dilakukan pada aspek/skala yang memiliki aitem lebih dari 5 yang melibatkan jumlah sampel yang besar (Bagozzi \& Heatherton, 1994). Kriteria yang digunakan untuk mengevaluasi model pengukuran yaitu reliabilitas komposit, validitas konvergen, dan validitas diskriminan (Hair, Hult, Ringle, \& Sarstedt, 2014). Evaluasi properti psikometris terhadap alat ukur yang digunakan melibatkan partisipan yang berbeda dengan partisipan penelitian yaitu 396 remaja berusia 12-21 tahun yang berada di Yogyakarta.
Gaya identitas

Identity Style Inventory (ISI-5; Berzonsky dkk., 2013) digunakan untuk mengukur gaya identitas yang dikonseptualisasikan oleh Berzonsky (1989) yaitu gaya informatif, normatif, dan menundamenghindar. Respons pada ISI-5 menggunakan lima pilihan respons skala Likert mulai dari 1 (sangat tidak sesuai) sampai 5 (sangat sesuai). Aitem ISI-5 berjumlah 27 aitem yang terdiri tiga sub skala yaitu gaya informatif (9 aitem), gaya normatif (9 aitem), dan gaya menunda-menghindar (9 aitem). Model pengukuran ISI-5 melibatkan 9 paket yang terdiri dari 3 paket pada sub skala gaya informatif, normatif, dan menunda-menghindar dengan setiap paket berisi 3 aitem.

Reliabilitas komposit dari model pengukuran ISI-5 menunjukkan reliabilitas komposit sebesar 0,826 untuk sub skala gaya informatif, 0,705 untuk sub skala gaya normatif, dan 0,723 untuk sub skala menunda-menghindar. Validitas konvergen dari model pengukuran ISI-5 menunjukkan bahwa semua paket secara signifikan mampu mengukur konstruk latennya dengan muatan faktor mulai dari 0,588 sampai 0,936 . Evaluasi mengenai validitas diskriminan dari model pengukuran ISI-5 menunjukkan bahwa semua paket memiliki muatan faktor (mulai dari 0,651 sampai 0,917) yang lebih tinggi dibandingkan muatan silangnya (mulai dari $-0,173$ sampai 0,292). Model pengukuran ISI-5 memiliki nilai CFI sebesar 0,962, GFI sebesar 0,965, dan RMSEA sebesar 0,067 .

\section{Dimensi identitas}

Utrecht-Management of Identity Commitments Scale (U-MICS; Crocetti, Rubini, \& Meeus, 2008) digunakan untuk mengukur dimensi identitas yang dikonseptualisasikan oleh Crocetti, Rubini, dan Meeus 
(2008) yaitu komitmen, eksplorasi mendalam, dan peninjauan kembali komitmen. Respons pada U-MICS menggunakan lima pilihan respons skala Likert mulai dari 1 (sangat tidak sesuai) sampai 5 (sangat sesuai). Aitem U-MICS berjumlah 26 aitem yang terdiri dari tiga sub skala yaitu komitmen (10 aitem), eksplorasi mendalam (10 aitem), dan peninjauan kembali komitmen (6 aitem). Model pengukuran U-MICS melibatkan 9 paket dengan masing-masing sub skala terdiri dari 3 paket untuk sub skala komitmen, eksplorasi mendalam, dan peninjauan kembali komitmen. Secara khusus, sub skala komitmen dan eksplorasi mendalam masing-masing terdiri dari 1 paket yang berisi 4 aitem dan 2 paket yang berisi 3 aitem sedangkan sub skala peninjauan kembali komitmen terdiri dari 3 paket yang berisi 2 aitem.

Model pengukuran U-MICS memiliki reliabilitas komposit sebesar 0,865 untuk sub skala komitmen, 0,709 untuk sub skala eksplorasi mendalam, dan 0,802 untuk sub skala peninjauan kembali komitmen. Validitas konvergen dari model pengukuran U-MICS menunjukkan bahwa semua paket secara signifikan mampu mengukur konstruk latennya dengan muatan faktor mulai dari 0,595 sampai 0,869 . Evaluasi mengenai validitas diskriminan dari model pengukuran U-MICS menunjukkan bahwa semua paket memiliki muatan faktor (mulai dari 0,696 sampai 0,868 ) yang lebih tinggi dibandingkan muatan silangnya (mulai dari -0,141 sampai 0,293). Model pengukuran UMICS nilai CFI sebesar 0,960, GFI sebesar 0,959, dan RMSEA sebesar 0,075.

\section{Status identitas}

\section{Ego Identity Process Questionnaire} (EIPQ; Balistreri, Busch-Rossnagel, \& Geisinger, 1995) digunakan untuk mengu- kur status identitas yang dikonseptualisasikan oleh Marcia (1966) yaitu diffusion, foreclosure, moratorium, dan achievement berdasarkan eksplorasi dan komitmen. EIPQ digunakan untuk mengukur eksplorasi dan komitmen pada delapan domain identitas yaitu empat domain ideologi (politics, religion, occupation, dan values) dan empat domain interpersonal (friendships, dating, sex roles, dan family). Respons pada EIPQ menggunakan enam pilihan respons skala Likert mulai dari 1 (sangat tidak sesuai) sampai 6 (sangat sesuai). Aitem EIPQ berjumlah 32 aitem yang terdiri dari 16 aitem yang mengukur eksplorasi dan 16 aitem yang mengukur komitmen. Model pengukuran dari EIPQ disusun dengan melibatkan 8 paket yang mewakili dua sub skala yaitu eksplorasi dan komitmen. Baik sub skala eksplorasi maupun komitmen memiliki 4 paket dengan masing-masing paket berisi 4 aitem.

Reliabilitas komposit dari model pengukuran EIPQ menunjukkan reliabilitas komposit sebesar 0,710 untuk sub skala eksplorasi dan 0,705 untuk sub skala komitmen. Validitas konvergen dari model pengukuran EIPQ menunjukkan bahwa semua paket secara signifikan mampu mengukur konstruk latennya dengan muatan faktor mulai dari 0,502 sampai 0,691 . Validitas diskriminan dari model pengukuran EIPQ menunjukkan bahwa semua paket memiliki muatan faktor (mulai dari 0,622 sampai 0,801) yang lebih tinggi dibandingkan muatan silangnya (mulai dari -0,096 sampai 0,223). Model pengukuran EIPQ memiliki nilai CFI sebesar 0,923, GFI sebesar 0,960, dan RMSEA sebesar 0,078.

\section{Teknik Analisis Data}

Data gaya dan dimensi identitas berupa data interval yang merupakan skor 
total dari masing-masing sub skala sehingga terdapat tiga skor gaya identitas yaitu gaya informatif, normatif, dan menunda-menghindar serta tiga skor dimensi identitas yaitu komitmen, eksplorasi mendalam, dan peninjauan kembali komitmen. Sedangkan data status identitas berupa data kategorikal yang terdiri dari empat status identitas yaitu status diffusion, foreclosure, moratorium, dan achievement. Klasifikasi status identitas ditentukan dengan cara membelah skor eksplorasi dan komitmen berdasarkan median yaitu median untuk skor eksplorasi sebesar 60 dan median untuk skor komitmen sebesar 62 .

Untuk menguji perbedaan gaya, dimensi, dan status identitas ditinjau dari gender dan kelompok usia dilakukan analisis MANOVA pada gaya dan dimensi identitas serta analisis chi-square pada status identitas dengan gender dan kelompok usia sebagai variabel independen. Untuk menguji hubungan gaya dengan dimensi identitas serta hubungan gaya dengan status identitas dilakukan analisis korelasi bivariat. Ketika menganalisis korelasi bivariat antara gaya dengan status identitas, data mengenai status identitas ditransformasikan ke dalam bentuk variabel dummy sehingga terdapat empat variabel dummy yaitu status diffusion, foreclosure, moratorium, dan achievement. Partisipan yang berada pada status diffusion, foreclosure, moratorium, dan achievement diberi kode 1 sedangkan partisipan yang tidak berada pada status tersebut diberi kode 0 .

\section{Hasil}

\section{Perbedaan Gaya, Dimensi, dan Status} Identitas ditinjau dari Gender

Hasil analisis MANOVA menunjukkan bahwa tidak terdapat perbedaan skor gaya identitas ditinjau dari gender (Wilks' $\lambda=0,984, \mathrm{~F}=2,465, \mathrm{p}>0,05)$. Hasil analisis univariat (Tabel 1) menunjukkan bahwa antara remaja laki-laki dan perempuan tidak ada perbedaan skor gaya informatif $(\mathrm{F}=1,624, \mathrm{p}>0,05)$ dan normatif $(\mathrm{F}=0,581$, $\mathrm{p}>0,05)$, tetapi ada perbedaan pada skor gaya menunda-menghindar $(\mathrm{F}=6,314, \mathrm{p}<$ $0,05)$. Remaja laki-laki memiliki skor gaya menunda-menghindar yang lebih tinggi dibandingkan dengan remaja perempuan.

Pada dimensi identitas, hasil analisis MANOVA menunjukkan adanya perbedaan skor dimensi identitas ditinjau dari gender (Wilks' $\lambda=0,909, \mathrm{~F}=14,748, \mathrm{p}<$ 0,001). Hasil analisis univariat (Tabel 2) menunjukkan bahwa terdapat perbedaan antara remaja laki-laki dan perempuan pada skor komitmen $(\mathrm{F}=4,115, \mathrm{p}<0,05)$, eksplorasi mendalam ( $\mathrm{F}=12,726, \mathrm{p}<$ 0,001), dan peninjauan kembali komitmen $(\mathrm{F}=14,042, \mathrm{p}<0,001)$. Remaja laki-laki memiliki skor peninjauan kembali komitmen yang lebih tinggi dibandingkan remaja perempuan, sedangkan remaja perempuan memiliki skor komitmen dan eksplorasi mendalam yang lebih tinggi daripada remaja laki-laki.

Hasil analisis chi-square yang digunakan untuk menguji perbedaan status identitas ditinjau dari gender menunjukkan bahwa tidak terdapat perbedaan status identitas antara remaja laki-laki dan perempuan $\left(\chi^{2}(3)=5,252, p>0,05\right)$. 
MUTTAQIN \& EKOWARNI

Tabel 1

Rata-rata (dan standar deviasi) skor gaya identitas ditinjau dari gender

\begin{tabular}{lccc}
\hline \multirow{2}{*}{ Gaya Identitas } & \multicolumn{2}{c}{ Gender } & F \\
\cline { 2 - 3 } & Laki-laki & Perempuan & \\
\hline Informatif & $35,21(4,33)$ & $35,69(3,51)$ & 1,624 \\
Normatif & $30,57(3,91)$ & $30,32(3,39)$ & 0,581 \\
Menunda-menghindar & $25,46(5,00)$ & $24,33(4,55)$ & $6,314^{*}$ \\
\hline
\end{tabular}

${ }^{*} \mathrm{p}<0,05{ }^{* *} \mathrm{p}<0,01{ }^{* * *} \mathrm{p}<0,001$

Tabel 2

Rata-rata (dan standar deviasi) skor dimensi identitas ditinjau dari gender

\begin{tabular}{lccc}
\hline \multirow{2}{*}{ Dimensi Identitas } & \multicolumn{2}{c}{ Gender } & F \\
\cline { 2 - 3 } & Laki-laki & Perempuan & $4,115^{*}$ \\
\hline Komitmen & $38,73(5,82)$ & $39,73(4,49)$ & $12,726^{* * *}$ \\
Eksplorasi mendalam & $35,93(4,79)$ & $37,36(3,76)$ & $14,042^{* * *}$ \\
Peninjauan kembali komitmen & $18,76(3,47)$ & $17,56(3,36)$ &
\end{tabular}

${ }^{*} \mathrm{p}<0,05{ }^{* *} \mathrm{p}<0,01^{* * *} \mathrm{p}<0,001$

Perbedaan Gaya, Dimensi, dan Status

Identitas ditinjau dari Kelompok Usia

Berdasarkan analisis MANOVA diketahui bahwa terdapat perbedaan skor gaya identitas ditinjau dari kelompok usia (Wilks' $\lambda=0,929, \mathrm{~F}=5,489, \mathrm{p}<0,001$ ). Hasil analisis univariat (Tabel 3) menunjukkan bahwa tidak terdapat perbedaan antara remaja awal, tengah, serta akhir pada skor gaya informatif $(F=0,904, p>$ $0,05)$ dan menunda-menghindar $(\mathrm{F}=0,011$, $\mathrm{p}>0,05)$, sedangkan pada skor gaya normatif ditemukan perbedaan antara remaja awal, tengah, dan akhir $(\mathrm{F}=10,617$, $p<0,001)$. Remaja awal memiliki skor gaya normatif yang lebih tinggi dibandingkan dengan remaja tengah dan akhir.
Pada dimensi identitas, hasil analisis MANOVA menunjukkan adanya perbedaan skor dimensi identitas ditinjau dari kelompok usia (Wilks' $\lambda=0,920, F=6,265$, $\mathrm{p}<0,001$ ). Hasil analisis univariat (Tabel 4) menunjukkan bahwa tidak terdapat perbedaan antara remaja awal, tengah, serta akhir pada skor komitmen ( $\mathrm{F}=1,467$, $\mathrm{p}>0,05)$ dan peninjauan kembali komitmen $(\mathrm{F}=3,022, \mathrm{p}>0,05)$, tetapi ada perbedaan pada skor eksplorasi mendalam $(\mathrm{F}=$ 8,784, $\mathrm{p}<0,001)$. Remaja tengah memiliki skor eksplorasi mendalam yang lebih tinggi dibandingkan dengan remaja awal dan akhir.

Tabel 3

Rata-rata (dan standar deviasi) skor gaya identitas ditinjau dari kelompok usia

\begin{tabular}{lcccc}
\hline \multirow{2}{*}{ Gaya Identitas } & \multicolumn{3}{c}{ Kelompok Usia Remaja } & \multirow{2}{*}{ F } \\
\cline { 2 - 4 } & Awal & Tengah & Akhir & \\
\hline Informatif & $35,13(3,55)$ & $35,47(4,41)$ & $35,75(3,84)$ & 0,904 \\
Normatif & $31,54(3,43)$ & $29,79(3,56)$ & $30,00(3,76)$ & $10,617^{* * *}$ \\
Menunda-menghindar & $24,93(4,98)$ & $24,89(4,39)$ & $24,85(5,05)$ & 0,011 \\
\hline
\end{tabular}

${ }^{*} \mathrm{p}<0,05{ }^{* *} \mathrm{p}<0,01{ }^{* * *} \mathrm{p}<0,001$ 
PEMBENTUKAN IDENTITAS REMAJA

Tabel 4

Rata-rata (dan standar deviasi) skor dimensi identitas ditinjau dari kelompok usia

\begin{tabular}{lcccc}
\hline \multirow{2}{*}{\multicolumn{1}{c}{ Dimensi Identitas }} & \multicolumn{3}{c}{ Kelompok Usia Remaja } & \multirow{2}{*}{ F } \\
\cline { 2 - 4 } & Awal & Tengah & Akhir & \\
\hline Komitmen & $39,77(5,64)$ & $38,74(4,83)$ & $39,19(5,13)$ & 1,467 \\
Eksplorasi mendalam & $35,83(3,69)$ & $37,80(4,71)$ & $36,31(4,40)$ & $8,784^{* * *}$ \\
Peninjauan kembali komitmen & $17,65(3,54)$ & $18,61(3,21)$ & $18,23(3,58)$ & 3,022 \\
\hline
\end{tabular}

${ }^{*} \mathrm{p}<0,05{ }^{* *} \mathrm{p}<0,01{ }^{* * *} \mathrm{p}<0,001$

Hasil analisis chi-square yang digunakan untuk menguji perbedaan status identitas ditinjau dari kelompok usia menunjukkan bahwa terdapat perbedaan status identitas antara remaja awal, tengah, dan akhir $\left(\chi^{2}(6)=27,294 \mathrm{p}<0,001\right)$. Remaja awal lebih banyak berada pada status diffusion dan foreclosure, remaja tengah lebih banyak berada pada status moratorium, sedangkan remaja akhir lebih banyak berada pada status achievement. Persentase status identitas ditinjau dari kelompok usia dapat dilihat pada tabel 5.

\section{Hubungan antara Gaya dan Dimensi Identitas}

Berdasarkan analisis korelasi bivariat diketahui bahwa gaya informatif berhubungan positif dengan komitmen $(\mathrm{r}=0,468, \mathrm{p}<0,001)$, eksplorasi mendalam $(\mathrm{r}=0,524, \mathrm{p}<0,001)$, dan peninjauan kembali komitmen $(\mathrm{r}=0,173, \mathrm{p}<0,001)$. Gaya normatif memiliki hubungan positif dengan komitmen $(r=0,356, p<0,001)$ dan eksplorasi mendalam $(\mathrm{r}=0,198, \mathrm{p}<0,001)$. Selain itu, hasil korelasi bivariat juga menunjukkan bahwa gaya menundamenghindar berhubungan negatif dengan komitmen $(\mathrm{r}=-0,198, \mathrm{p}<0,001)$ dan eksplorasi mendalam $(r=-0,108, p<0,05)$, tetapi memiliki hubungan yang positif dengan peninjauan kembali komitmen $(\mathrm{r}=$ 0,181, $\mathrm{p}<0,001)$. Hasil analisis korelasi bivariat antara gaya dan dimensi identitas dapat dilihat pada tabel 6 .

Tabel 5

Persentase status identitas ditinjau dari kelompok usia

\begin{tabular}{lccc}
\hline \multirow{2}{*}{ Status Identitas } & \multicolumn{3}{c}{ Kelompok Usia Remaja } \\
\cline { 2 - 4 } & Awal & Tengah & Akhir \\
\hline Diffusion & $29,33 \%$ & $20,67 \%$ & $14,00 \%$ \\
Foreclosure & $32,00 \%$ & $21,33 \%$ & $27,33 \%$ \\
Moratorium & $12,00 \%$ & $32,67 \%$ & $26,00 \%$ \\
Achievement & $26,67 \%$ & $25,33 \%$ & $32,67 \%$ \\
\hline
\end{tabular}

Tabel 6

Korelasi bivariat antara gaya dan dimensi identitas

\begin{tabular}{lccc}
\hline \multirow{2}{*}{ Gaya Identitas } & \multicolumn{3}{c}{ Dimensi Identitas } \\
\cline { 2 - 4 } & Komitmen & Eksplorasi mendalam & Peninjauan kembali komitmen \\
\hline Informatif & $0,468^{* * *}$ & $0,524^{* * *}$ & $0,173^{* * *}$ \\
Normatif & $0,356^{* * *}$ & $0,198^{* * *}$ & 0,069 \\
Menunda-menghindar & $-0,198^{* * *}$ & $-0,108^{*}$ & $0,181^{* * *}$ \\
\hline
\end{tabular}

${ }^{*} \mathrm{p}<0,05^{* *} \mathrm{p}<0,01^{* * *} \mathrm{p}<0,001$ 
Hubungan antara gaya dan status identitas

Hasil korelasi bivariat menunjukkan bahwa gaya informatif memiliki hubungan positif dengan status moratorium $(\mathrm{r}=$ $0,105, \mathrm{p}<0,05)$ dan achievement $(\mathrm{r}=0,192$, $\mathrm{p}<0,001)$, tetapi berhubungan negatif dengan status diffusion $(\mathrm{r}=-0,263, \mathrm{p}<$ $0,001)$. Gaya normatif berhubungan positif dengan status foreclosure $(\mathrm{r}=0,096, \mathrm{p}<$ $0,05)$ dan achievement $(\mathrm{r}=0,119, \mathrm{p}<0,05)$, tetapi memiliki hubungan negatif dengan status diffusion $(\mathrm{r}=-0,125, \mathrm{p}<0,01)$ dan moratorium ( $\mathrm{r}=-0,106, \mathrm{p}<0,05)$. Hasil korelasi bivariat juga menunjukkan bahwa gaya menunda-menghindar berhubungan positif dengan status diffusion ( $r=0,205$, $\mathrm{p}<0,001)$, tetapi memiliki hubungan negatif dengan status foreclosure $(\mathrm{r}=-0,098$, $\mathrm{p}<0,05)$ dan achievement $(\mathrm{r}=-0,107, \mathrm{p}<$ $0,05)$. Hasil korelasi bivariat antara gaya dan status identitas dapat dilihat pada tabel 7 .

\section{Diskusi}

Temuan mengenai perbedaan gender pada gaya, dimensi, dan status identitas menggambarkan kesempatan yang dimiliki remaja laki-laki dan perempuan dalam proses pembentukan identitas. Kondisi remaja Indonesia yang mayoritas tumbuh dan berkembang dalam keluarga patrilineal membuat laki-laki dan perempuan mendapatkan perlakuan yang berbeda yang lebih menguntungkan lakilaki (Hidajadi, 2001). Hal ini tergambarkan dari anak laki-laki lebih banyak dilatih untuk pekerjaan yang dilakukan di luar rumah sedangkan anak perempuan dilatih untuk melakukan tugas-tugas rumah tangga (Suardiman, 2011). Dengan demikian, remaja laki-laki diprediksi akan memiliki lebih banyak kesempatan untuk mengeksplorasi identitasnya daripada remaja perempuan. Namun sebaliknya, temuan penelitian ini mengindikasikan bahwa remaja laki-laki dan perempuan memiliki kesempatan yang sama dalam proses pembentukan identitas, bahkan remaja perempuan dapat lebih mengoptimalkan kesempatan tersebut dibandingkan dengan laki-laki.

Temuan ini tidak terlepas dari modernisasi dan perubahan konstruksi sosial mengenai peran laki-laki dan perempuan di Indonesia yang berusaha mewujudkan kesetaraan gender dalam berbagai bidang. Berry, Poortinga, Segall, dan Dasen (2002) menjelaskan bahwa konstruksi sosial memengaruhi variasi peran gender lakilaki dan perempuan berdasarkan waktu dan budaya. Perubahan peran gender di Indonesia tergambarkan dari kegiatan remaja perempuan pada tahun 1961 yang lebih banyak mengurus rumah tangga dan menikah berubah menjadi lebih banyak menempuh pendidikan dan bekerja pada tahun 2000 (Adioetomo, 2006). Perubahan ini tidak terlepas dari perubahan yang terjadi dalam sistem sosial, misalnya keluarga dan sekolah. Pada lingkungan keluarga, orang tua mulai memberikan

\section{Tabel 7}

Korelasi bivariat antara gaya dan status identitas

\begin{tabular}{lcccc}
\hline \multirow{2}{*}{ Gaya Identitas } & \multicolumn{4}{c}{ Status Identitas } \\
\cline { 2 - 5 } & Diffusion & Foreclosure & Moratorium & Achievement \\
\hline Informatif & $-0,263^{* * *}$ & $-0,053$ & $0,105^{*}$ & $0,192^{* * *}$ \\
Normatif & $-0,125^{* *}$ & $0,096^{*}$ & $-0,106^{*}$ & $0,119^{*}$ \\
Menunda-menghindar & $0,205^{* * *}$ & $-0,098^{*}$ & $-0,019$ & $-0,107^{*}$ \\
\hline
\end{tabular}

${ }^{*} \mathrm{p}<0,05^{* *} \mathrm{p}<0,01^{* * *} \mathrm{p}<0,001$ 
kesempatan yang sama untuk anak lakilaki dan perempuan untuk memilih pendidikan dan pekerjaan. Pada lingkungan sekolah, siswa memperoleh pengetahuan baik secara langsung maupun tidak langsung tentang kesetaraan gender melalui kurikulum, buku teks, dan proses pembelajaran (Analytical and Capacity Development Partnership, 2013).

Perbedaan pencapaian pembentukan identitas antara remaja laki-laki dan perempuan dapat disebabkan remaja perempuan memiliki prioritas yang lebih tinggi pada domain karier, politik, agama, hubungan interpersonal, dan peran gender dibandingkan dengan laki-laki (Alberts, Mbalo, \& Ackermann, 2003; Sandhu, 2006). Prioritas tersebut memengaruhi remaja perempuan mencari informasi tambahan untuk mengevaluasi komitmen yang sudah dipilih supaya semakin sesuai dengan tujuan dan potensi yang dimiliki (Crocetti dkk., 2008; Crocetti, Schwartz, Fermani, Klimstra, \& Meeus, 2012). Kurangnya prioritas bagi remaja laki-laki pada berbagai domain identitas menyebabkan mereka kurang memiliki informasi mengenai alternatif identitas yang sesuai dengan tujuan dan potensi yang dimiliki. Hal ini yang menyebabkan remaja laki-laki memiliki identitas yang tidak stabil sehingga selalu mempertimbangkan untuk memilih komitmen yang lain ketika komitmen yang dipilih tidak lagi memuaskan (Berzonsky dkk., 2013; Crocetti, Klimstra, Hale, Koot, \& Meeus, 2013).

Temuan mengenai perbedaan gaya, dimensi, dan status identitas ditinjau dari kelompok usia menggambarkan perubahan pembentukan identitas pada masa remaja yang sesuai dengan kondisi di Indonesia. Remaja awal di Indonesia masih tergantung pada keluarga dan diperlakukan sebagai individu yang belum dewasa sehingga mereka akan mematuhi keinginan atau harapan orang tua dan mengabaikan keinginan pribadinya (Nilan, Parker, Bennett, \& Robinson, 2011). Selain itu, berbagai domain identitas (misalnya karier) belum menjadi masalah konkret bagi remaja awal di Indonesia yang pada umumnya masih menempuh pendidikan di Sekolah Menengah Pertama (Sarwono, 2013).

Remaja tengah di Indonesia yang pada umumnya sedang menempuh pendidikan di Sekolah Menengah Atas mulai mempersiapkan diri terkait dengan berbagai domain identitas (misalnya karier). Mereka mulai mencari informasi sebanyak mungkin mengenai jurusan di perguruan tinggi atau pekerjaan yang sesuai minat dan potensi yang dimiliki (Sarwono, 2013). Pada tahapan usia remaja tengah, remaja memang cenderung menggunakan gaya kognitif yang berorientasi pada informasi dengan mulai mencari dan mengumpulkan informasi mengenai berbagai domain identitas (Crocetti dkk., 2009, 2012) dan fokus pada pengalaman yang mereka miliki (Stephen, Fraser, \& Marcia, 1992).

Berbeda dengan remaja awal dan tengah, berbagai domain identitas (misalnya karier) sudah menjadi masalah konkret bagi remaja akhir di Indonesia (Sarwono, 2013). Kondisi ini tidak terlepas dari remaja akhir di Indonesia yang pada umumnya sedang menempuh pendidikan di perguruan tinggi. Hal ini menggambarkan bahwa mereka telah mengambil keputusan mengenai pilihan karier yang sesuai dengan minat dan kemampuan berdasarkan informasi yang diperoleh sebelumnya. Remaja akhir mampu mencapai level tertinggi dalam mengintegrasikan berbagai dimensi identitas karena mereka lebih mampu berpikir rasional dan mengambil keputusan yang tepat, serta 
memiliki lebih banyak pengalaman (Boyes \& Chandler, 1992; Phinney, 2008).

Hubungan antara gaya, dimensi, dan status identitas menunjukkan keterkaitan model pembentukan identitas remaja pada konteks Indonesia. Remaja Indonesia pada umumnya tinggal dalam keluarga besar dengan orang tua cenderung dominan terhadap anak (Sarwono, 2013; Suardiman, 2011). Dominasi orang tua terhadap anak tergambarkan melalui kecenderungan orang tua memberikan aturan atau batasan yang mengatur perilaku anak (Suardiman, 2011). Kondisi ini mengarahkan remaja Indonesia cenderung mematuhi keinginan atau harapan orang tua dan mengabaikan keinginan pribadinya (Nilan dkk., 2011). Mematuhi keinginan orang tua telah dianggap sebagai perwujudan rasa hormat dari seorang anak terhadap orang tuanya pada masyarakat Indonesia sebagai bentuk interdependensi diri yang bersifat hirarkhis (Moffatt, 2012; Sartana \& Helmi, 2014; Suardiman, 2011). Selain itu, kepatuhan anak terhadap keinginan dan petunjuk orang tua akan menjadi kepuasan dan kebanggaan tersendiri bagi orang tua (Suardiman, 2011).

Meskipun ada kecenderungan remaja Indonesia untuk patuh terhadap keinginan dan petunjuk orang tua, namun penelitian ini menunjukkan bahwa remaja Indonesia tidak hanya menggunakan gaya normatif tetapi juga menggunakan gaya informatif dan menunda-menghindar. Hal ini disebabkan karena adanya kemungkinan remaja untuk mematuhi, berkompromi, maupun mempertimbangkan harapan orang tua dan tuntutan masyarakat ketika mengambil keputusan terkait dengan berbagai domain identitas (Marcia, 1966, 1993). Sesuai dengan hasil penelitian, penggunaan gaya identitas yang berbeda dapat menunjukkan perbedaan dimensi dan status identitas remaja pada konteks
Indonesia. Remaja dengan gaya informatif akan menunjukkan komitmen, eksplorasi mendalam, dan peninjauan kembali komitmen serta berada pada status moratorium atau achievement, remaja dengan gaya normatif akan menunjukkan komitmen dan eksplorasi mendalam serta berada pada status foreclosure, sedangkan remaja dengan gaya menunda-menghindar akan menunjukkan peninjuan kembali komitmen dan berada pada status diffusion.

\section{Kesimpulan}

Kesimpulan dari penelitian ini adalah model gaya, dimensi, dan status identitas dapat digunakan untuk memahami pembentukan identitas remaja pada konteks Indonesia. Pada konteks Indonesia, remaja laki-laki dan perempuan memiliki kesempatan yang sama dalam pembentukan identitas, bahkan remaja perempuan dapat lebih mengoptimalkannya. Seiring dengan bertambahnya usia, remaja pada konteks Indonesia dapat mencapai pembentukan identitas yang optimal. Sesuai dengan kemampuan adaptasi terhadap konteks yang dihadapi, remaja pada konteks Indonesia dapat menggunakan berbagai gaya identitas yang berkaitan erat dengan dimensi dan status identitas sebagai satu kesatuan komponen pembentukan identitas.

\section{Saran}

Saran untuk penelitian selanjutnya adalah perlu mempertimbangkan konteks yang lebih spesifik (misalnya domisili tempat tinggal dan budaya) serta perlu mengeksplorasi faktor-faktor yang memengaruhi pembentukan identitas agar dapat memahami pembentukan identitas remaja pada konteks Indonesia secara lebih komprehensif. 


\section{Kepustakaan}

Adams, G. R., \& Marshall, S. K. (1996). A developmental social psychology of identity: Understanding the personin-context. Journal of Adolescence, 19(5), 429-442.

http://doi.org/10.1006/jado.1996.0041

Adioetomo, S. M. (2006). Wajah baru penduduk Indonesia. In T. H. Hull (Ed.), Masyarakat, kependudukan, dan kebijakan di Indonesia (pp. 155-205). Jakarta: PT Equinox Publishing Indonesia.

Alberts, C., Mbalo, N. F., \& Ackermann, C. J. (2003). Adolescents' perceptions of the relevance of domains of identity formation: A South African crosscultural study. Journal of Youth and Adolescence, 32(3), 169-184.

http://doi.org/10.1023/A:102259130290 9

Analytical and Capacity Development Partnership. (2013). Gender equality in education in Indonesia. Jakarta: Balitbang-Kemendikbud.

Arbuckle, J. L. (2012). IBM SPSS Amos 21 users guide. Amos Development Corporation.

Bagozzi, R. P., \& Heatherton, T. F. (1994). A general approach to representing multifaceted personality constructs: Application to state self-esteem. Structural Equation Modeling: A Multidisciplinary Journal, 1(1), 35-67. http://doi.org/10.1080/10705519409539 961

Balistreri, E., Busch-Rossnagel, N. A., \& Geisinger, K. F. (1995). Development and preliminary validation of the Ego Identity Process Questionnaire. Journal of Adolescence, 18(2), 179-192. http://doi.org/10.1006/jado.1995.1012

Bang, H., \& Montgomery, D. (2013).
Wisdom and ego-identity for Korean and American late adolescents. Journal of Cross-Cultural Psychology, 44(5), 807-831. http://doi.org/10.1177/ 0022022112466941

Baumeister, R. F., \& Muraven, M. (1996). Identity as adaptation to social, cultural, and historical context. Journal of Adolescence, 19(5), 405-416. http://doi.org/10.1006/jado.1996.0039

Berman, S. L., Weems, C. F., Rodriguez, E. T., \& Zamora, I. J. (2006). The relation between identity status and romantic attachment style in middle and late adolescence. Journal of Adolescence, 29(5), 737-748.

http://doi.org/10.1016/j.adolescence.20 05.11.004

Berry, J. W., Poortinga, Y. H., Segall, M. H., \& Dasen, P. R. (2002). Cross-culltural psychology: Research and applications. Cambridge: University Press.

Berzonsky, M. D. (1989). Identity style: Conceptualization and measurement. Journal of Adolescent Research, 4(3), 268-282.

http://doi.org/10.1177/07435548894300 2

Berzonsky, M. D. (2004). Identity processing style, self-construction, and personal epistemic assumptions: A social-cognitive perspective. European Journal of Developmental Psychology, 1(4), 303-315. http://doi.org/10.1080/17405620444000 120

Berzonsky, M. D. (2011). A social-cognitive perspective on identity construction. In S. J. Schwartz, K. Luyckx, \& V. L. Vignoles (Eds.), The handbook of identity theory and research (pp. 55-76). New York: Springer.

Berzonsky, M. D., Soenens, B., Luyckx, K., Smits, I., Papini, D. R., \& Goossens, L. 
(2013). Development and validation of the revised Identity Style Inventory (ISI-5): Factor structure, reliability, and validity. Psychological Assessment, 25(3), 893-904.

http://doi.org/10.1037/a0032642

Bosma, H. A., \& Kunnen, E. S. (2001). Determinants and mechanisms in ego identity development: A review and synthesis. Developmental Review, 21(1), 39-66.

http://doi.org/10.1006/drev.2000.0514

Boyes, M. C., \& Chandler, M. (1992). Cognitive development, epistemic doubt, and identity formation in adolescence. Journal of Youth and Adolescence, 21(3), 277-304.

http://doi.org/10.1007/BF01537019

Busch, H., \& Hofer, J. (2011). Identity, prosocial behavior, and generative concern in German and Cameroonian Nso adolescents. Journal of Adolescence, 34(4), 629-638.

http://doi.org/10.1016/j.adolescence.20 10.09.009

Côté, J. E., \& Levine, C. (1988). A critical examination of the ego identity status paradigm. Developmental Review, 8(2), 147-184. http://doi.org/10.1016/02732297(88)90002-0

Crocetti, E., Klimstra, T. A., Hale, W. W., Koot, H. M., \& Meeus, W. H. (2013). Impact of early adolescent externalizing problem behaviors on identity development in middle to late adolescence: A prospective 7-year longitudinal study. Journal of Youth and Adolescence, 42(11), 1745-1758. http://doi.org/10.1007/s10964-0139924-6

Crocetti, E., Rubini, M., Berzonsky, M. D., \& Meeus, W. H. (2009). Brief report: The Identity Style Inventory Validation in Italian adolescents and college students. Journal of Adolescence, 32(2), 425-433.

http://doi.org/10.1016/j.adolescence.20 08.04.002

Crocetti, E., Rubini, M., \& Meeus, W. H. (2008). Capturing the dynamics of identity formation in various ethnic groups: Development and validation of a three-dimensional model. Journal of Adolescence, 31(2), 207-222.

http://doi.org/10.1016/j.adolescence.20 07.09.002

Crocetti, E., Schwartz, S. J., Fermani, A., Klimstra, T. A., \& Meeus, W. H. (2012). A cross-national study of identity status in Dutch and Italian adolescents. European Psychologist, 17(3), 171-181.

http://doi.org/10.1027/10169040/a000076

Erikson, E. H. (1950). Childhood and society. New York: W.W. Norton \& Company, Inc.

Erikson, E. H. (1968). Identity: Youth and crisis. New York: W.W. Norton \& Company, Inc.

Eryigit, S., \& Kerpelman, J. L. (2011). Cross-cultural investigation of the link between identity processing styles and the actual work of identity in the career domain. Child $\mathcal{E}$ Youth Care Forum, 40(1), 43-64. http://doi.org/10.1007/s10566-0109117-3

Graf, S. C., Mullis, R. L., \& Mullis, A. K. (2008). Identity formation of United States American and Asian Indian adolescents. Adolescence, 43(169), 5769.

Hair, J. F., Hult, G. T. M., Ringle, C. M., \& Sarstedt, M. (2014). A primer on partial least squares structural equation modeling (PLS-SEM). Thousand Oaks, CA: Sage Publications, Inc. 
Hambleton, R. K. (2005). Issues, designs and technical guidelines for adapting tests into multiple languages and cultures. In R. K. Hambleton, P. F. Merenda, \& C. D. Spielberger (Eds.), Adapting educational and psychological tests for cross-cultural assessment (pp. 3-38). Mahwah, NJ, US: Erlbaum.

Hidajadi, M. (2001). Hubungan ibu dan anak perempuan: Sebuah distorsi? Jurnal Perempuan, 16, 7-15.

Klimstra, T. A., Hale, W. W., Raaijmakers, Q. A. W., Branje, S. J. T., \& Meeus, W. H. (2010). Identity formation in adolescence: Change or stability? Journal of Youth and Adolescence, 39(2), 150-162.

http://doi.org/10.1007/s10964-0099401-4

Kroger, J. (2000). Ego identity status research in the new millennium. International Journal of Behavioral Development, 24(2), 145-148. http://doi.org/10.1080/01650250038325 0

Kroger, J., \& Marcia, J. E. (2011). The identity statuses: Origins, meanings, and interpretation. In S. J. Schwartz, K. Luyckx, \& V. L. Vignoles (Eds.), The handbook of identity theory and research (pp. 31-53). New York: Springer.

Kroger, J., Martinussen, M., \& Marcia, J. E. (2010). Identity status change during adolescence and young adulthood: A meta-analysis. Journal of Adolescence, 33(5), 683-698.

http://doi.org/10.1016/j.adolescence.20 09.11.002

Laghi, F., Baiocco, R., Liga, F., Guarino, A., \& Baumgartner, E. (2013). Identity status differences among Italian adolescents: Associations with time perspective. Children and Youth
Services Review, 35(3), 482-487. http://doi.org/10.1016/j.childyouth.201 2.12 .018

Lee, C.-T., \& Beckert, T. E. (2012). Taiwanese adolescent cognitive autonomy and identity development: The relationship of situational and agential factors. International Journal of Psychology, 47(1), 39-50.

http://doi.org/10.1080/00207594.2011.5 72972

Marcia, J. E. (1966). Development and validation of ego-identity status. Journal of Personality and Social Psychology, 3(5), 551-558. http://doi.org/10.1037/h0023281

Marcia, J. E. (1993). The ego identity status approach to ego identity. In J. E. Marcia, A. S. Warterman, D. R. Matterson, S. L. Archer, \& J. L. Orlofsky (Eds.), Ego identity: A handbook for psychosocial research (pp. 1-21). New York: Springer.

Meeus, W. H., Van De Schoot, R., Keijsers, L., Schwartz, S. J., \& Branje, S. J. T. (2010). On the progression and stability of adolescent identity formation: A five-wave longitudinal study in early-to-middle and middleto-late adolescence. Child Development, 81(5), 1565-1581.

http://doi.org/10.1111/j.1467-

8624.2010.01492.x

Moffatt, A. (2012). Indonesian cultural profile. Australia: Diversicare.

Möller-Leimkühler, A. M. (2003). The gender gap in suicide and premature death or: Why are men so vulnerable? European Archives of Psychiatry and Clinical Neuroscience, 253(1), 1-8. http://doi.org/10.1007/s00406-0030397-6

Nilan, P., Parker, L., Bennett, L., \& Robinson, K. (2011). Indonesian youth 
looking towards the future. Journal of Youth Studies, 14(6), 709-728. http://doi.org/10.1080/13676261.2011.5 80523

Phinney, J. S. (2005). Ethnic identity in late modern times: A response to Rattansi and Phoenix. Identity, 5(2), 187-194. http://doi.org/10.1207/s1532706xid050 2_7

Phinney, J. S. (2008). Bridging identities and disciplines: Advances and challenges in understanding multiple identities. New Directions for Child and Adolescent Development, (120), 97-109. http://doi.org/10.1002/cd.218

Sandhu, D. (2006). Gender differences in adolescent identity formation. Pakistan Journal of Psychological Research, 21(1-2), 29-40.

Santrock, J. W. (2011). Life-span development (13th ed.). New York: McGraw-Hill.

Sartana, \& Helmi, A. F. (2014). Konsep diri remaja Jawa saat bersama teman. Jurnal Psikologi, 41(2), 190-204.

Sarwono, S. W. (2013). Psikologi remaja edisi revisi. Jakarta: Rajawali Pers.

Schwartz, S. J. (2001). The evolution of Eriksonian and Neo-Eriksonian identity theory and research: A review and integration. Identity, 1(1), $7-58$.

http://doi.org/10.1207/S1532706XSCH WARTZ

Schwartz, S. J., \& Montgomery, M. J. (2002). Similarities or differences in identity development? The impact of acculturation and gender on identity process and outcome. Journal of Youth and Adolescence, 31(5), 359-372. http://doi.org/10.1023/A:101562860855 3

Schwartz, S. J., Zamboanga, B. L., Meca, A., \& Ritchie, R. A. (2012). Identity around the world: An overview. New Directions for Child and Adolescent Development, (138), 1-18. http://doi.org/10.1002/cad.20019

Shwalb, D. W., Shwalb, B. J., Nakazawa, J., Hyun, J.-H., Le, H. Van, \& Satiadarma, M. P. (2010). East and Southeast Asia: Japan, South Korea, Vietnam, and Indonesia. In Handbook of Cultural Developmental Scienc (pp. 445-464). New York: Psychology Press.

Stephen, J., Fraser, E., \& Marcia, J. E. (1992). Moratorium-achievement (MAMA) cycles in lifespan identity development: Value orientations and reasoning system correlates. Journal of Adolescence, 15(3), 283-300. Retrieved from

http://www.ncbi.nlm.nih.gov/pubme d/1447414

Suardiman, S. P. (2011). Psikologi usia lanjut. Yogyakarta: Gadjah Mada University Press.

Utomo, I. D. (2006). Kehidupan perempuan: Lima puluh tahun perubahan dan kontinuitas. In T. H. Hull (Ed.), Masyarakat, kependudukan, dan kebijakan di Indonesia (pp. 85-154). Jakarta: PT Equinox Publishing Indonesia.

Vleioras, G., \& Bosma, H. A. (2005). Are identity styles important for psychological well-being? Journal of Adolescence, 28(3), 397-409.

http://doi.org/10.1016/j.adolescence.20 04.09.001

Wängqvist, M., \& Frisén, A. (2013). Swedish 18-year-olds' identity formation: Associations with feelings about appearance and internalization of body ideals. Journal of Adolescence, 36(3), 485-493.

http://doi.org/10.1016/j.adolescence.20 
13.02.002

Yoder, A. E. (2000). Barriers to ego identity status formation: A contextual qualification of Marcia's identity status paradigm. Journal of Adolescence, 23(1), 95-106.

http://doi.org/10.1006/jado.1999.0298

Zimmermann, G., Mahaim, E. B., Mantzouranis, G., Genoud, P. A., \& Crocetti, E. (2012). Brief report: The
Identity Style Inventory (ISI-3) and the Utrecht-Management of Identity Commitments Scale (U-MICS): Factor structure, reliability, and convergent validity in French-speaking university students. Journal of Adolescence, 35(2), 461-465.

http://doi.org/10.1016/j.adolescence.20 10.11.013 